9. Miyai K, Harada $T$, Nose $O$, Yabuuchi $H$, Mizuta $H$, Nishi $K$, Fujie $T$, Nakatani K 1980 Transient infantile hyperthyrotropinemia. In: Stockigt JR, Nagataki S (eds) Thyroid Research VIII. Australian Academy of Science, Canberra, $\mathrm{p} 33$

10. Miyai K, Ishibashi K, Kawashima M 1981 Two-site immunoenzymometric assay for thyrotropin in dried blood samples on filter paper. Clin Chem 27:1421

11. Miyai K, Ishibashi K, Kumahara Y 1976 Enzyme immunoassay of thyrotropin. Clin Chim Acta 67:263
12. Miyai K, Nishi K, Kawashima M, Oura T, Tsuruhara T 1976 An improved assay of thyrotropin in dried blood samples on filter paper as a screening test for neonatal hypothyroidism. Clin Chim Acta 73:241

13. Miyai K, Oura T, Kawashima M, Tsuruhara T, Hase Y, Ichihara K, Amino N, Nishi K, Fujie T, Nankatani K, Azukizawa M, Nose O 1978 A new method of paired thyrotropin assay as a screening test for neonatal hypothyroidism. J Clin Endocrinol Metab 47;1028

14. Yang J, Kennedy MT 1979 Evaluation of enzyme-linked immunosorbent assay for the serodiagnosis of amebiasis. J Clin Microbiol 10:778

\title{
Apparent Absence of Cystic Fibrosis Sweat Factor on Ion-selective and Transport Properties of the Perfused Human Sweat Duct
}

\author{
JAN BIJMAN AND PAUL M. QUINTON \\ Division of Biomedical Sciences, University of California, Riverside, California 92521-0121 [J.B., P.M.Q.] and \\ Department of Physiology, University of California, Los Angeles, California 90024 [P.M.Q.]
}

\begin{abstract}
Several previous studies have reported that a substance in exocrine products from cystic fibrosis (CF) patients is inhibitory to the transport of $\mathrm{NaCl}$ in several biological preparations. We have recently developed techniques for studying a target $\mathrm{CF}$ tissue, the eccrine sweat duct, and determined that salt absorption in the CF sweat duct appears to be decreased due to an impermeability to Cl. To determine whether this property might be induced, we have examined the sweat from patients with $C F$ for potential influences on the ion-reabsorptive and ion-selective properties of sweat ducts from normal subjects. Isolated segments of sweat ducts from healthy volunteers were microperfused in vitro with concentration-adjusted sweat collected after thermal stimulation from $C F$ patients and from normal subjects. The eccrine sweat duct may be best considered as a tight epithelium through which the mucosal uptake of $\mathrm{NaCl}$ proceeds via separate $\mathrm{Na}^{+}$and $\mathrm{Cl}^{-}$pathways. As such, inhibitory actions of CF fluids should be exerted via an inhibition on one, or both, pathways, and should be expected to 1 ) inhibit the electrolyte transport activity and 2) alter the ion-selective properties of normal ductal tissue. We were unable to detect any effect of $\mathrm{CF}$ sweat on either property of the normal duct. (Pediatr Res 18:1292-1296, 1984)
\end{abstract}

Abbreviations

CF, cystic fibrosis

PD, potential difference

Received January 2, 1984; accepted June 5, 1984.

Reprint requests may be addressed to Jan Bijman, Division of Biomedical

Sciences, University of California, Riverside, CA 92521-0121.

This work was supported by awards from the Getty Oil Co., the Gillette Co. and by National Institutes of Health Grant AM 26547.
The inherited autosomal recessive disease, cystic fibrosis, is a generalized disorder of the exocrine glands. One of the most characteristic features of the disease is abnormally elevated $\mathrm{NaCl}$ in the sweat which is due to decreased electrolyte absorption in the ductal segment of the sweat gland. It has been postulated that the abnormal electrolyte transport in the CF sweat duct is due to a transport-inhibiting substance present in CF sweat (6, 11). It was further suggested that a similar inhibitory substance may be present in other exocrine secretions since saliva from CF patients was reported to inhibit electrolyte reabsorptive processes in other tissues as well $(8,22,24)$.

Many of the types of tissues that apparently exhibit abnormal electrolyte transport in cystic fibrosis also retain several characteristics in common. That is, the sweat duct (13), the salivary duct $(1,4)$, the colon $(24)$, and the respiratory mucosa (7) are all sensitive to the $\mathrm{Na}^{+}$channel blocker, amiloride. All are capable of generating a lumen-negative transepithelial electrical potential. And in addition with the possible exception of respiratory epithelia, most, if not all, of the above tissues are characterized by hypertonic fluid transport, stimulated by aldosterone, and are reported to be inhibited by exocrine secretions from $C F$ patients. To our knowledge, the respiratory mucosa has not been examined for these properties. These observations and characteristics have led to the suggestion that a $\mathrm{CF}$ inhibitory substance may act similarly to amiloride $(21,24)$. If the substance is a transport inhibitor, and particularly if it resembles amiloride, we should not only expect inhibition of ion transport, but also alterations in electrophysiological properties of the normal duct as well.

In addition, there are at least two other reasons for re-examining the possibility of a transport inhibitory substance in $\mathrm{CF}$ sweat. First, we have now developed methods for assaying ion transport activity and electrophysiological properties of the isolated sweat duct in vitro making it possible to test the response of a tissue that is known to be markedly affected in the disease. This feature, in addition to the ability to control conditions maximally, should make the preparation an optimal system for bioassay. Secondly, we recently found that the negative potential 
in the lumen of CF duct is significantly hyperpolarized compared to the normal sweat duct and that this phenomenon appears to be due to a decrease in the $\mathrm{Cl}$ permeability of the $\mathrm{CF}$ ductal tissue $(15,17)$. Aside from the fact that this decrease in $\mathrm{Cl}$ permeability may also explain the decreased net uptake of salt in the CF duct (16), this finding provides a new parameter by which the effects of potentially inhibitory substances might be detected.

By microperfusing the isolated sweat duct with Ringer's solutions and concentration-adjusted human sweat, we tested $\mathrm{CF}$ sweat for the presence of substances which might affect electrolyte transport properties. If CF sweat could be shown to be inhibitory, we hoped to determine further whether the effect involves $\mathrm{Na}^{+}$ blocking amiloride-like properties or whether the effect is principally due to properties which block $\mathrm{Cl}$ movement and thereby might explain $\mathrm{Cl}$ impermeability in $\mathrm{CF}$ tissue. Central to these questions is the issue of whether the abnormal function of the CF sweat duct and other organs is induced by an extrinsic agent or is caused by an intrinsic defect in tissues specifically affected in the disease.

\section{MATERIALS AND METHODS}

The methods for measuring $\mathrm{Na}^{+}$uptake in isolated perfused sweat ducts (13) as well as for measuring transepithelial potential differences (15) have been described previously. In brief, small skin biopsies (3-mm diameter) were taken from the back over the region of the scapula from healthy adult male volunteers giving informed consent. Using a dissecting microscope, the glands were dissected from the connective tissue. After uncoiling the gland tubule, a segment of the reabsorptive duct $(2-4 \mathrm{~mm})$ was cut free and mounted with modified micropipettes for perfusion (5). After mounting, the temperature was increased from $5-7$ to $35-37^{\circ} \mathrm{C}$.

Sweat was obtained from CF and healthy adult male volunteers. Gross sweat was collected by enclosing most of the torso in a plastic tube which was sealed carefully to the skin with surgical tape to prevent evaporation. Sweating was stimulated by exposure to increased ambient temperature in a warm room $\left(37^{\circ}\right.$ C) for 30 to $60 \mathrm{~min}$ with intermittent voluntary exercise. Two $10-\mathrm{ml}$ volumes of sweat were collected sequentially. Usually, only the second volume was used as a microperfusate. Since previous investigators $(9,10)$ have reported that inhibitory effects of CF secretions were lost if the secretions were exposed to glass or heated, all of our sweat collections were processed in plastic containers and maintained at $4^{\circ} \mathrm{C}$ until used experimentally. Since the microperfusion pipette is constructed of glass (Kimax), the sweat was unavoidably exposed to this glass during microperfusion. However, the perfusion pipette was always rinsed with more than 10 volumes of sweat perfusate before perfusion was initiated. Upon several occasions, pipettes were used which had been treated with Prosil 28 (PCR, Inc., Gainesville, Florida) to render the internal surface hydrophobic and presumably nonreactive. No differences in results were observed with these pipettes.

Since optimal solution composition is different for $\mathrm{Na}^{+}$uptake measurements and for PD measurements, the composition of aliquots of collected sweat was adjusted accordingly. To optimize $\mathrm{Na}^{+}$uptake, sweat was adjusted to approximate the composition of the primary secretion in the sweat gland $(18,19)$ by adding sufficient $\mathrm{NaCl}$ and $\mathrm{NaHCO}_{3}$ to bring the final concentration of $\mathrm{Na}^{+}$to $136 \mathrm{mM}$ and of $\mathrm{HCO}_{3}^{-}$to $24 \mathrm{mM}$ (Table 1). To optimize $\mathrm{PD}$ measurements, the $\mathrm{pH}$ was adjusted to 6.5 to lower the $\mathrm{HCO}_{3}{ }^{-}$concentration and reduce any contribution from it to the net PD. Sufficient $\mathrm{NaCl}$ was added to bring the final concentration of $\mathrm{Na}^{+}$to $150 \mathrm{mM}$ (Table 2). This $\mathrm{pH}$ adjustment should not be detrimental to any inhibitory substances since $\mathrm{CF}$ sweat is generally secreted at a $\mathrm{pH}$ more than one unit lower than this adjustment (Tables 1 and 2). The concentration of $\mathrm{K}^{+}$and $\mathrm{Ca}^{2+}$
Table 1. Electrolyte composition and $\mathrm{pH}$ of sweat collected from control $(C)$ and cystic fibrosis subjects before and after adjustment with $\mathrm{NaCl}$ and $\mathrm{NaHCO}_{3}{ }^{*}$

\begin{tabular}{lccrrr}
\hline & $\begin{array}{c}\mathrm{Na}^{+} \\
(\mathrm{mM})\end{array}$ & $\begin{array}{c}\mathrm{Cl}^{-} \\
(\mathrm{mM})\end{array}$ & $\begin{array}{c}\mathrm{K}^{+} \\
(\mathrm{mM})\end{array}$ & $\begin{array}{c}\mathrm{Ca}^{2+} \\
(\mathrm{mM})\end{array}$ & \multicolumn{1}{c}{$\mathrm{pH}$} \\
\hline Collected sweat & $114.3 \dagger$ & $112.5 \dagger$ & $8.5 \ddagger$ & 1.5 & $4.9 \dagger$ \\
(CF) & \pm 11.5 & \pm 9.7 & \pm 0.4 & \pm 0.3 & \pm 0.3 \\
Collected sweat & 58.7 & 48.3 & 5.3 & 1.0 & 6.0 \\
(C) & & \pm 12.2 & \pm 0.3 & \pm 0.3 & \pm 0.2 \\
Adjusted sweat & 136.3 & 111.5 & 8.2 & 1.5 & 7.5 \\
$\quad$ (CF) & \pm 3.9 & \pm 3.7 & \pm 0.5 & \pm 0.3 & \pm 0.1 \\
Adjusted sweat & 136.3 & 107.3 & 5.3 & 1.0 & 7.5 \\
(C) & \pm 0.9 & \pm 2.7 & \pm 0.3 & \pm 0.3 & \pm 0.1 \\
\hline
\end{tabular}

* The mean age was $24 \pm 5$ and $26 \pm 4$ years in controls and $C F$ subjects, respectively. The adjusted sweat was used in experiments measuring Na uptake ( $n=4$ in both populations).

$\dagger p<0.01$.

$\ddagger p<0.05$.

Table 2. Electolyte composition and $\mathrm{pH}$ of sweat collected from control $(C)$ and cystic fibrosis subjects before and after adjusting with $\mathrm{NaCl}^{*}$

\begin{tabular}{lccrrr}
\hline & $\begin{array}{c}\mathrm{Na}^{+} \\
(\mathrm{mM})\end{array}$ & $\begin{array}{c}\mathrm{Cl}^{-} \\
(\mathrm{mM})\end{array}$ & $\begin{array}{c}\mathrm{K}^{+} \\
(\mathrm{mM})\end{array}$ & $\begin{array}{c}\mathrm{Ca}^{2+} \\
(\mathrm{mM})\end{array}$ & \multicolumn{1}{c}{$\mathrm{pH}$} \\
\hline Collected sweat & $115.8 \dagger$ & $111.2 \dagger$ & $7.2 \ddagger$ & 1.6 & 5.3 \\
(CF) & \pm 10.3 & \pm 8.6 & \pm 0.3 & \pm 0.3 & \pm 0.5 \\
Collected sweat & 55.8 & 47.8 & 4.9 & 1.1 & 6.0 \\
$\quad$ (C) & \pm 11.8 & \pm 9.5 & \pm 0.5 & \pm 0.3 & \pm 0.5 \\
Adjusted sweat & 149.6 & 141.4 & 7.2 & 1.6 & 6.5 \\
$\quad$ (CF) & \pm 2.5 & \pm 3.2 & \pm 0.3 & \pm 0.3 & \pm 0.3 \\
Adjusted sweat & 150.2 & 142.4 & 5.1 & 1.1 & 6.5 \\
(C) & \pm 2.0 & \pm 4 & \pm 0.3 & \pm 0.3 & \pm 0.3 \\
\hline
\end{tabular}

* The mean age was $19 \pm 1$ and $21 \pm 1$ years in control and CF subjects, respectively. The adjusted sweat was used in experiments measuring intraluminal potential differences ( $n=6$ in both populations).

$\dagger p<0.01$.

$\ddagger p<0.05$.

was somewhat higher in CF sweat (Tables 1 and 2), but the differences were so small that no attempts were made to adjust their concentration. Debris was removed from all sweat samples by centrifugation at $2600 \times g$ at $4^{\circ} \mathrm{C}$ for $5 \mathrm{~min}$.

Bath and perfusate Ringer's solutions for $\mathrm{Na}^{+}$uptake studies contained the following components (mM): $110 \mathrm{NaCl}, 24$ $\mathrm{NaHCO}_{3}, 10$ glucose, $5.0 \mathrm{KCl}, 2.0 \mathrm{CaCl}_{2}, 2.1 \mathrm{NaH}_{2} \mathrm{PO}_{4}$, and 1.2 $\mathrm{MgSO}_{4}$. Bovine serum albumin, Fraction IV, was added to the dissecting bath solution at a concentration of $1.0 \%$. Solutions were equilibrated with $5 \% \mathrm{CO}_{2}$ and $95 \% \mathrm{O}_{2}$ gas to bring the $\mathrm{pH}$ to 7.4. The bath and perfusate Ringer's solutions for electrophysiological measurements contained the following constituents (mM): $150 \mathrm{NaCl}, 10$ glucose, $2.125 \mathrm{~K}_{2} \mathrm{HPO}_{4}, 0.375 \mathrm{KH}_{2} \mathrm{PO}_{4}$, $1.0 \mathrm{CaSO}_{4}$, and $1.0 \mathrm{MgSO}_{4}$. When necessary, $\mathrm{NaCl}$ was replaced with $\mathrm{Na}$ gluconate to provide an impermeant anion. The $\mathrm{pH}$ was adjusted to 7.4 .

All data are given as mean values \pm SE. Statistical significance was evaluated applying Student's $t$ test for paired or unpaired samples as appropriate. During the $\mathrm{Na}^{+}$uptake experiments, we controlled perfusion rates by varying the hydrostatic pressure on the perfusate. Several perfusion rates at regular intervals between 3 and $30 \mathrm{nl} / \mathrm{min}$ were obtained for each experimental condition. The $\mathrm{Na}^{+}$uptake values were expressed as the change in $\mathrm{Na}^{+}$ concentration per duct length $\left(\mathrm{mM} \mathrm{Na}^{+} / \mathrm{mm}\right.$ duct) and plotted as function of the perfusion rate $(\mathrm{nl} / \mathrm{min})$. These plots were 
linearized by assuming a dual logarithmic relationship between the two parameters. Regression values for the slope were $0.73<$ $r<0.94$. For individual sweat ducts, a paired analysis $F$ test of homogenate regression lines was applied for testing the difference between the $\mathrm{Na}^{+}$uptake from artificial sweat and adjusted sweat. For clarity, we have plotted the $\mathrm{Na}^{+}$values expressed in terms of flux $\left(\mathrm{nEq} / \mathrm{cm}^{2} / \mathrm{s}\right)$ at regular interpolated intervals of the perfusion rate (see Fig. 1, $A$ and $B$ ).

\section{RESULTS}

Sodium uptake from sweat ducts perfused with adjusted sweat from healthy and CF individuals. In a set of four experiments, the isolated human sweat duct was first perfused with Ringer's solution at different rates to measure the net $\mathrm{Na}^{+}$uptake (Fig. $1 A$ ). Maximal and stable $\mathrm{Na}^{+}$uptake rates were found for perfusion rates $>15 \mathrm{nl} / \mathrm{min}$. The maximal $\mathrm{Na}^{+}$uptake rate was 8 $\mathrm{nEq} / \mathrm{cm}^{2} / \mathrm{s}$ assuming a mean ductal luminal diameter of $15 \mu \mathrm{m}$ as measured under perfused conditions. Subsequently, the ducts were perfused with adjusted sweat from healthy volunteers and again the net $\mathrm{Na}^{+}$uptake was measured at different perfusion rates (Fig. 1 $A$ ). In four other ducts, the protocol was repeated replacing adjusted normal sweat with concentration-adjusted $C F$ (Fig. $1 B$ ). As is shown in Figure $1, A$ and $B$, for both types of sweat the $\mathrm{Na}^{+}$reabsorption from sweat is reduced slightly, but not significantly, when compared to the uptake from control Ringer's, which may be due to the possibility that $\mathrm{Na}^{+}$uptake capacity of the tissue decreases with time. However, at any perfusion rate, paired analysis showed no statistical difference between the $\mathrm{Na}^{+}$uptake from $\mathrm{NaCl}$-Ringer's and either adjusted type of adjusted sweat $(p>0.10)$.

Ion selectivity of the reabsorptive duct of the human sweat glands. The response of the PD in the normal sweat duct to several electrolytes is shown in Figure 2. After mounting the ducts, we perfused the tissue first with $150 \mathrm{mM}$ Na-gluconate. The PD under this condition was $-90.0 \pm 9.2 \mathrm{mV}$ (lumen negative) which was depolarized to $-72.5 \pm 5.0 \mathrm{mV}$ when the $\mathrm{Na}$-gluconate was replaced by $10 \mathrm{mM} \mathrm{NaCl}$ plus $140 \mathrm{mM} \mathrm{Na}-$ gluconate. The PD depolarized further to $-7.8 \pm 1.0 \mathrm{mV}$ when gluconate was completely replaced by $\mathrm{Cl}^{-}$. The fact that the direction and magnitude of the change in the PD in response to

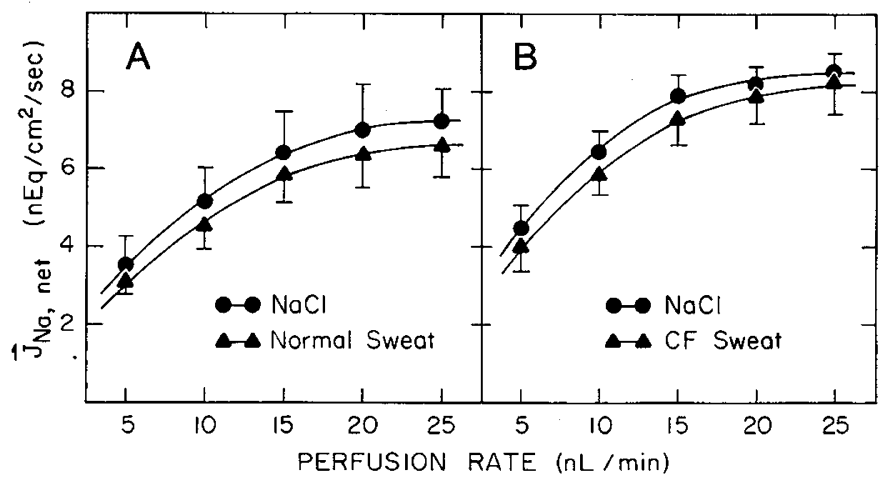

Fig. 1. $A$, influence of normal sweat on the $\mathrm{Na}^{+}$uptake $\left(\mathrm{nEq} / \mathrm{cm}^{2} / \mathrm{s}\right)$ from in vitro perfused sweat ducts of healthy volunteers at different perfusion velocities ( $\mathrm{nl} / \mathrm{min}$ ). The ducts were first perfused with a $\mathrm{NaCl}$ solution at different rates and the protocol was repeated with a sweat solution obtained from healthy volunteers. The $\mathrm{Na}^{+}$concentrations of both solutions were identical (Table 1). At any perfusion rate, there was no significant difference (see "Materials and Methods") in the $\mathrm{Na}^{+}$uptake from the two solutions, although there is a tendency for the $\mathrm{Na}^{+}$reabsorption capacity of the tissue to decrease with time $(n=4) . B$, influence of $\mathrm{CF}$ sweat on the $\mathrm{Na}^{+}$uptake $\left(\mathrm{nEq} / \mathrm{cm}^{2} / \mathrm{s}\right)$ from in vitro perfused sweat ducts of healthy volunteers at different perfusion velocities ( $\mathrm{nl} / \mathrm{min})$. No significant differences were found between the $\mathrm{Na}^{+}$uptake from a $\mathrm{NaCl}$ solution and adjusted CF sweat at any perfusion rate $(n=4)$.

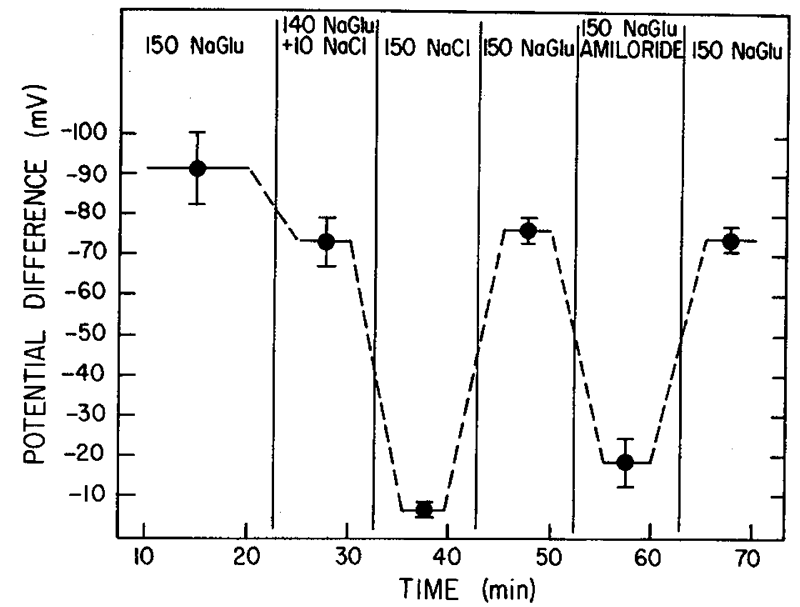

Fig. 2. Ion-selective properties of the normal human sweat duct. In time, the tissue was perfused with different solutions as indicated at the top (concentration in $\mathrm{mM}$; Glu, gluconate). The large effects of substituting gluconate for $\mathrm{Cl}^{-}\left(\mathrm{Na}^{+}\right.$constant) on the PD indicate the presence of a highly conductive $\mathrm{Cl}$ transport pathway in the tissue. In the absence of $\mathrm{Cl}^{-}$, the luminal $\mathrm{Na}^{+}$electrode characteristics of the cells are shown by perfusing $100 \mu \mathrm{M}$ amiloride which caused a large (reversible) depolarization of the $\mathrm{PD}(n=4)$.

changes in $\mathrm{Cl}^{-}$concentration are approximated by the Nernst relation indicates the presence of a highly conductive transductal pathway for $\mathrm{Cl}^{-}$. Reintroduction of gluconate in the lumen of the duct hyperpolarized the PD $(-76.6 \pm 3.3 \mathrm{mV})$ towards its original value (note that the PD did not return to its original value which may be due to a slight decrease in the active transport capacity of the tissue or its ability to maintain large electrochemical gradients over long periods). In the absence of $\mathrm{Cl}^{-}$, the $\mathrm{Na}^{+}$ electrode characteristics of the luminal membrane were tested by adding the sodium diuretic compound amiloride $(100 \mu \mathrm{M})$ to the perfusate, causing a sharp depolarization of the PD $(-19.5$ $\pm 4.5 \mathrm{mV}$; Fig. 2). These experiments showed that the tissue maintained good ion-selective properties for more than $80 \mathrm{~min}$.

Effects of perfused sweat on the PD. Prior to perfusing the sweat ducts with sweat, six freshly mounted ducts were first perfused with $150 \mathrm{mM}$ Na-gluconate which resulted in the generation of a large PD $(-99.6 \pm 7.5 \mathrm{mV})$ across the epithelium (Fig. 3). Subsequently stable PDs were measured for both CF sweat and normal sweat, $-7.5 \pm 1.0$ and $-7.0 \pm 1.2 \mathrm{mV}$, respectively $(p>0.5)$, perfused for 20 -min periods. To test the general influence of sweat on the PD of the ducts, a $150 \mathrm{mM}$ $\mathrm{NaCl}$ solution was perfused subsequently for $10 \mathrm{~min}$. Under those conditions, the PD, $-6.6 \pm 1.1 \mathrm{mV}$, was not different from the PD measured with either type of sweat or when Ringer's solution was used as the preceding perfusate, $p>0.1$. Neither were there any differences in PD when control sweat was used as the first perfusate (data not shown). Also, after about $70 \mathrm{~min}$, the PD hyperpolarized when perfused with Na-gluconate to a value $(-67.3 \pm 10.3 \mathrm{mV})$ not significantly different from the value obtained for ducts perfused with other solutions after such periods $(-76.6 \pm 3.3 \mathrm{mV})$ as is shown in Figure $1(p>0.5)$.

\section{DISCUSSION}

In two previous studies, CF sweat was reported to inhibit net $\mathrm{Na}^{+}$uptake immediately after exposing the luminal surface of the normal sweat duct to CF sweat. In the first (6), sweat from normal subjects was normalized to $\mathrm{CF}$ sweat by the addition of $\mathrm{NaCl}$. Both $\mathrm{CF}$ and normal sweat were retroinjected into the ducts of single sweat glands in normal subjects. Subsequent pharmacological stimulation and analysis of sweat indicated that $\mathrm{Na}^{+}$reabsorption was decreased in glands retroinjected with $\mathrm{CF}$ sweat. Although there was considerable overlap and spread in 


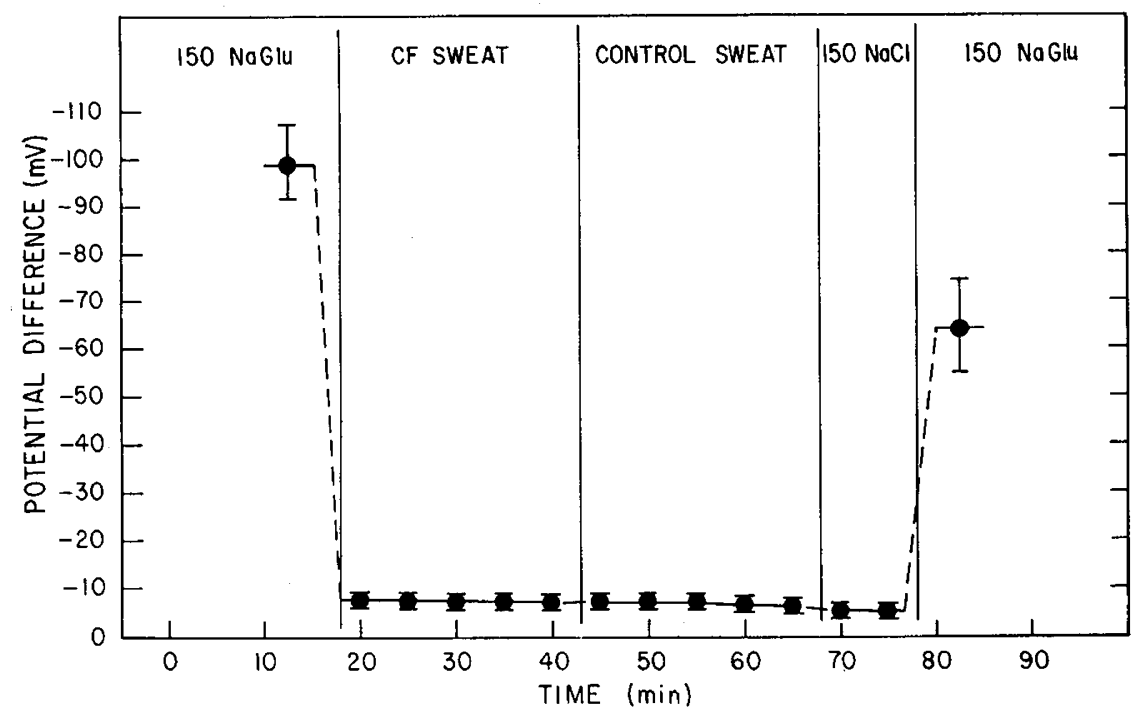

Fig. 3. Effects of perfused sweat on the electrical potential difference across sweat ducts of healthy volunteers. The ducts were first perfused with $150 \mathrm{mM}$ Na-gluconate $(\mathrm{NaGlu})$. CF sweat and sweat from healthy volunteers, both perfused for more than 20 min, gave the same PD which was not different from the PD measured when a $150 \mathrm{mM} \mathrm{NaCl}$ solution was perfused. (The $\mathrm{Na}^{+}$concentration in the sweat was adjusted close to 150 $\mathrm{mM}$, Table 2.) At $t=85 \mathrm{~min}$, the PD in the presence of Na-gluconate in the lumen was not different from the PD measured in ducts not exposed to sweat over such a period (cf. Fig. 1) $(n=6)$.

values, these results suggested the presence of a substance in $\mathrm{CF}$ sweat that was fast acting and relatively irreversible since an inhibitory effect was noted within a few minutes after retroinjection and was not washed away by subsequent secretions from the gland. In the second set of studies (11), the secretory coil was removed from single glands imbedded in skin biopsies from normal subjects. The remaining reabsorptive duct was then microperfused with sweat from cystic fibrosis or normal subjectsnormalized with $\mathrm{NaCl}$. Again, $\mathrm{Na}^{+}$absorption was reported to be reduced in ducts microperfused with CF sweat. An explanation for the discrepancies between these two earlier reports and the present results is not readily available. In our experiments on $\mathrm{Na}^{+}$uptake, we adjusted the sweat for $\mathrm{HCO}_{3}{ }^{-}$concentration to optimize transport conditions which was not done in the previous studies. We also used a more sensitive analytical method. But these differences do not offer a self-evident explanation of the consistent differences reported. In the in vivo study, the degree of retroinjection of the individual sweat glands apparently was subjective. Variations in the retrograde procedure may have introduced degrees of trauma which may have affected results. Unfortunately, details of the method of stimulation, injection, collection, and analysis of sweat are lacking so that further evaluation is difficult. In the previous in vitro microperfusion study, a number of factors were reported to affect the viability of the preparations so that $40 \%$ of the results were disgarded (11). It was also reported that $\mathrm{Na}^{+}$reabsorption could be sustained in vitro only if normal sweat was used as perfusate. In our work, we have found no such requirement (Figs. $1 A, 1 B$, and 3). It is possible that these early results were affected by the stain, methylene blue, used to identify single glands for dissection from the skin. Variation in the uptake of stain may have contributed to uncontrolled differences in reabsorptive capacities. No stains were used in the present study and the functional integrity of the sweat ducts seems to be relatively independent of such factors as protein in the medium or time after biopsy and the reported reabsorptive activity (11) appears to be less than about $25 \%$ of that found in the present study (Fig. 1, $A$ and $B$ ). Furthermore, the earlier work reported that $\mathrm{Na}^{+}$reabsorption from $\mathrm{CF}$ ducts was not inhibited when adjusted normal sweat was used as the perfusate, suggesting that effects of an inhibitor CF substance is readily reversible. This report is in contrast to other descriptions in which the CF-related defect persists for extended periods (6, $8,17,22)$.
Related experiments have been performed using the rat parotid gland as a model assay system. Both saliva $(8-10,22)$ and sweat (8) retroinjected into the rat parotid gland were reported to inhibit $\mathrm{Na}^{+}$reabsorption in this tissue. An evaluation of these results is beyond the scope of this discussion, but it seems peculiar that these secretions should be effective in inhibiting $\mathrm{Na}^{+}$transport in the rat parotid gland when no significant abnormalities in electrolyte content in secretions from the same organ in CF subjects has been identified $(12,14)$, but it may not be the CF parotid gland that secretes an inhibitory substance (23). In contrast to many of the preparations used previously to assay for the presence of inhibitory factors, particularly those requiring retroinjection, the present microperfusion system seems more direct and perhaps better controlled. For example, due to the difficulty in controlling retroinjection procedures, reproducibility of earlier work required that data be accepted only when the volume of retroinjected fluid was closely matched to gland weight (22).

In another study, an inhibitory substance in CF saliva was suggested to be analogous to amiloride in its action since mixed sublingual-submaxillary saliva from both $\mathrm{CF}$ and normal subjects was observed to inhibit about $15 \%$ of the $\mathrm{Na}^{+}$absorption in the colon from $\mathrm{Na}^{+}$-starved rats (24). Although the results were statistically significant, the data showed CF saliva to be only $3 \%$ more inhibitory to net $\mathrm{Na}^{+}$transport than normal saliva. Amiloride inhibited $91 \%$ of the activity.

If sweat contained an amiloride-like substance, we should have detected some effect on both net $\mathrm{Na}^{+}$absorption and electrical properties of the sweat duct. Amiloride effectively blocks $\mathrm{Na}^{+}$ absorption in the intact gland and microperfused duct (13) and dramatically reduces hyperpolarization in the normal duct perfused with Na-gluconate (Fig. 2). These results suggest that the apical membrane of the sweat duct cells possesses a $\mathrm{Na}^{+}$-selective pathway in parallel with a highly conductive anion $\left(\mathrm{Cl}^{-}\right)$shunt, similar to the rabbit salivary duct $(2,4)$. An amiloride-like substance in CF sweat should have decreased the net uptake of $\mathrm{Na}^{+}$by blocking its entry into the duct cell through the apical membrane. Likewise, perfusion with CF sweat should have caused a depolarization of the luminal PD, and if the substance is not easily rinsed away, the hyperpolarization created by replacing $\mathrm{Cl}^{-}$with the impermeant gluconate anion should have been reduced also. As is shown in Figs. $1 A, 1 B$, and 3, there was virtually no difference between the effects of adjusted $C F$ and 
normal sweat perfusate on either net transport or $\mathrm{Na}^{+}$-selective pathway across the duct. Neither was there any significant difference between the effects of adjusted sweat and Ringer's solution perfusate.

Recent evidence (3) indicates that the $\mathrm{Na}^{+}$mechanism is as active in the CF duct as in the normal duct and that the decreased uptake of $\mathrm{NaCl}$ can probably be attributed largely, if not completely, to the impermeability of $\mathrm{Cl}^{-}$. Thus, a transport inhibitory substance in $\mathrm{CF}$ sweat should act by blocking the $\mathrm{Cl}^{-}$selective shunt, in which case net $\mathrm{Na}^{+}$transport should decrease and the luminal PD should hyperpolarize. That is, blocking the $\mathrm{Cl}^{-}$ permeability in the normal duct should mimic the effects of removing the anion shunt as can be accomplished by substituting the impermeable gluconate for the permeable $\mathrm{Cl}^{-}$anion (Fig. 1). Again, however, there is no evidence that either $\mathrm{CF}$ or normal sweat had any detectable effect on net $\mathrm{Na}^{+}$transport (Fig. 1, $A$ and $B$ ) or on the electrical properties of the duct (Fig. 2).

In view of the numerous reports that the inhibition of ion transport in CF exocrine glands may be due to an inhibitory factor $(11,21)$, it is perhaps disappointing that the present results show no inhibitory substance in CF sweat capable of altering ductal ion transport. We cannot prove that an inhibtory factor in our CF sweat samples has not been inactivated, but since we took great care to collect and handle the samples as previously described $(8,11)$ (J. A. Mangos, personal communication; B. Bowman, personal communication), we believe this possibility is unlikely. As a concluding consideration, we note that isolated CF ducts in vitro retain their low permeability to $\mathrm{Cl}^{-}$for hours after resection and hours during microperfusion with completely defined media. This result in itself contradicts earlier reports that the effect is readily reversible $(11,24)$ and demonstrates that the defect is either inherent to the tissue or due to a relatively irreversible inhibitory substance which acts only after a long period of exposure to the tissue.

Acknowledgments. We deeply appreciate the excellent technical assistance of Ms. Diane Hannon. We thank Dr. Gokhale of the Department of Statistics, University of California, Riverside, for developing the statistics program.

\section{REFERENCES}

1. Augustus J, Bijman J, van Os CH, Slegers JFG 1977 High conductance in an epithelial membrane not due to extracellular shunting. Nature 268:657-658

2. Augustus J, Bijman J, van Os CH 1978 Electrical resistance of rabbit submaxillary main duct: a tight epithelium with leaky cell membranes. $\mathrm{J}$ membr Biol 43:203-226

3. Bijman J, Quinton PM 1984 Abnormal electrolyte transport in cystic fibrosis sweat ducts as a function of $\mathrm{Cl}$ impermeability. Am J Physiol 247:C3-C9

4. Bijman J. Cook DI, van Os CH 1983 Effect of amiloride on the transport parameters of the main duct of the rabbit mandibular gland. Pflugers Arch Eur J Physiol 398:96-102

5. Burg MB, Grantham J, Abramov M, Orloff J 1977 Preparation and study of fragments of single rabbit nephrons. Am J Physiol 210:1293-1298

6. Kaiser D, Drack E, Rossi E 1970 Effect of cystic fibrosis sweat on $\mathrm{Na}$ reabsorption by the normal sweat gland. Lancet 1:1003

7. Knowles M, Gatzy J, Boucher R 1981 Increased bioelectric potential difference across respiratory epithelia in cystic fibrosis. N Engl J Med 305:1489-1495

8. Mangos JA, McSherry NR 1967 Sodium transport: inhibitory factor in sweat of patients with cystic fibrosis. Science 158:135-136

9. Mangos JA, McSherry NR 1968 Studies on the mechanism of inhibition of sodium transport in cystic fibrosis of the pancreas. Pediatr Res $2: 378-384$

10. Mangos JA, McSherry NR, Benke PJ 1967 A sodium transport inhibitory factor in the saliva of patients with cystic fibrosis of the pancreas. Pediatr Res 1:436-442

11. Mangos JM 1973 Microperfusion study on the sweat gland abnormality in cystic fibrosis. Tex Rep Biol Med 31:651-663

12. Martinez JR 1982 Alterations in salivary gland structure and function in cystic fibrosis. In: Quinton PM, Martinez JR, Hopfer U (eds) Fluid and Electrolyte Abnormalities in Exocrine Glands in Cystic Fibrosis. San Francisco Press, Inc, San Francisco, pp 125-142

13. Quinton PM 1981 Effects of some transport inhibitors on secretion and reabsorption in intact and perfused single human sweat glands. Pflug Arch Eur J Physiol 391:309-313

14. Quinton PM 1984 Exocrine glands. In Taussig L (ed) Cystic Fibrosis. ThiemeStratton, New York, pp 304-307

15. Quinton PM 1983 Chloride impermeability in cystic fibrosis. Nature 301:421422

16. Quinton PM 1982 Abnormalities in electrolyte secretion in cystic fibrosis sweat glands due to decreased anion permeability. In: Quinton PM, Martinez JR, Hopfer U (eds) Fluid and Electrolyte Abnormalities in Exocrine Glands in Cystic Fibrosis. San Francisco Press, Inc., San Francisco, pp 53-76

17. Quinton PM, Bijman J 1983 Higher bioelectric potentials due to decreased chloride absorption in the sweat glands of patients with cystic fibrosis. $\mathrm{N}$ Engl J Med 308:1185-1189

18. Sato K 1977 The physiology, pharmacology, and biochemistry of the eccrine sweat gland. In: Adrian RH, Holzer H, Kramer K, Linden RJ, Miescher PA, Rasmussen H, Trendelenburg U, Vogt W (eds) Reviews of Physiology, Biochemistry and Pharmacology, Springer-Verlag, Berlin, pp 51-131

19. Sato K 1982 Mechanism of eccrine sweat secretion. In: Quinton PM, Martinez JR, Hopfer U (eds) Fluid and Electrolyte Abnormalities in Exocrine Glands in Cystic Fibrosis. San Francisco Press, Inc, San Francisco, pp 35-52

20. Schulz IJ, Fromter E 1968 Mikropunktionsuntersuchungen an Schweissdrusen von Mucoviscidose Patienten und Gesundenen Versuchspersonen. In: Windorfer H, Stephan U (eds) Mucoviscidose. George Thieme Verlag, Stuttgart, pp 12-21

21. Sorscher EJ, Breslow JL 1982 Cystic fibrosis: a disorder of calcium-stimulated secretion and transepithelial sodium transport. Lancet 1:368-370

22. Taylor A, Mayo JW, Boat TF, Matthews LW 1974 Standardized assay for the sodium reabsorption inhibitory effect and studies of its salivary gland distribution in patients with cystic fibrosis. Pediatr Res 8:861-865

23. Wiesman UN 1972 Flow rates and electrolytes in minor salivary gland saliva in normal subjects and patients with cystic fibrosis. Lancet 2:510-512

24. Will PC, Taylor A, Lebowitz JL, Dearborn DG, Hopfer U 1980 Saliva from patients with cystic fibrosis inhibits amiloride-sensitive sodium transport. Pediatr Res 14:1245-1249 